could not have been the disciple of a man who died in 922 . 'Abdullah Marwāiñd was a very well-known man, both as a public servant and as a writer, and Sām Mìrzā speaks "of his history as having considerable vogue. If the anonymous life is not his 'Tārikh Shāhi, what has become of the latter? If we suppose that he died in 932 this would agree with the opinions of Professors Rieu, Ross, and Browne that the life was written shortly after the accession of Shāh Tahmāsp. As regards the mention of M. Zamān Mīrzā's death in the life, I would suggest that this fact, which occurred in $94 \%$, was added by a copyist or by 'Abdullah's son, Mīrzā Mūmīn. He seems to have been connected with Muhammad Zamān, for the two names are bracketed together in Khwandāmīr's notice of Mīrzā Mūmīn (loc. cit., 554a), and it is evident from the long details about M. Zamān which are given in the anonymous life that he and the writer must have known one another. Mìrzà Mūmīn was Sām Mìrzā's preceptor, and a well-known writer and calligrapher. He afterwards entered Tahmāsp's service, but left him for some reason and went to India (not improbably in company with M. Zamān), and died there. According to De Sacy this occurred in 948, but $I$ do not find this date in the British Museum copy of Sām Mīrzā's work.

Finally, if we must take the date 922 as the correct date of 'Abdullah's death, may we not hold that the latter's life of Shāh Isma'il was continued and completed by the son.

Notices of 'Abdullah Marwārīd will be found in Mìr 'Alì Shīr's Majālis ; in Daulat Shāh, p. 515 of Mr. Browne's edition, and in Bābar's Memoirs, in his account of the eminent men of Sulțān Ḥsain's Court.

H. Beveringe.

\title{
3. A Camboijan Mahávamsa.
}

Würzburg, Sanderring 20. September 14, 1901 .

My dear Professor Rhys Davids,-During the last three months I have possessed here at our University's 
library a MS. from Paris, containing, to judge from the catalogue in the J.P.T.S., 1882, p. 35, the Mahavamsa in Cambodjan writing. But the catalogue is mistaken. The MS., which is not badly written, although it abounds with errors of every sort, and far exceeds in size the Mahāvamsa, as we know it from the published text, contains a secondary work, embodying the Mabāv. (i.e. the thirty-eight paricchedas), only with many liberties in adapting it to the general plan the author had in view. You will better understand his intentions by the colophon. I quote from it the following verses:-

Buddhavạ̣sạ̣ Mahāvaṃsạ̣ sikkhīnañ ca samāhaṭạ̣

Thūpavamsam gahetvāna sampiṇditvāna ekato atthato gandhato câpi yuttato cāpi ettha ca ayuttạ̣ pāliruddhạ̣ vā yadi passati kiñcăpi pubbāparam viloketvā vicāretvā punappunạ̣ dhìmantānam gahetabbam gahetabbam na dosato tividhopapadānam $\left[\right.$ written $\left.{ }^{\circ} \mathrm{dhoppapa}^{\circ}\right]$ gatiyo $^{1}$ duvidhā [written duvu ${ }^{\circ}$ ti ca

tasmā upaparikkhitvā veditabbam [written ${ }^{\circ}$ [bā] vibhāvin̄a antarāyạ̣ vinā cāyạ̣ yathā siddhim upāgatā tathā kalyānasamkappā siddhim gacchanti [written ${ }^{\circ}$ cchati] pāṇinạ̣.

Then follow two ślokas containing the usual prayers. Then in prose: anena puññena mayā katena sikkheyyạ [written ${ }^{\circ}$ yyā] tạ̣ dhammavarạ jinassa, paññāya sīlena kusalena cāti [written cāto or cāgo] anāgate ketumagyạ̣ [? ketumāghyam ?] bhaveyyam, yadā sutvāna saddhammạ̣ Mettayyass' [thus clearly] eva santike pasanno pïtiy $\bar{a}$ mayhạ̣ pabbaji jinasāsane Moggalläno ti nāmāhaṃ. Then follow two slokas of benedictions.

This Moggallāna, of whose date we as yet know nothing, was certainly no great poet, but, so far as he was led by the wish to banish darkness wherever the reader of the existent

1 In Cambrijan $g$ and $t$ are the same. I read gatiyo, but the meaning of this verse is not quite intelligible to me. 
Mahāvamasa may meet with it, and to amplify more and more the original text, his task is executed pretty well. To demonstrate this, I beg to point out only two instances.

(1) After the first four verses of the first chapter follows a section which bears the subscription: Uruvelagamanam nițthitam, of about 490 slokas, beginning with Pubbe kira gavesanto bodhiñānạm narāsabho.

From bodhito navame mãse (ŝl. 19 of the $\mathrm{Mv}$.) the compilation agrees with the text, but already in the second half it disagrees and makes a digression, relating in detail and with many interspersed dialogues the affairs in Lanka on Buddha's first visit there. Whereas the original text consists of 24 slokas from Bodhito (v. 19) to the conclusion (v. 43) of the Mahiyanganangamana, Moggallāna has brought: them up to more than 200, a few only being identical with those in the printed text of the Mv. In other sections the additions are smaller, but every section has additions.

(2) In ch. v (ed. Turnour, p. 41) is simply related how 'Tissa propounded to the king (Asoka) the Tittirajātaka. From the circumstances under which this was done it follows that Jāt. iii, 64 sqq. is meant. In the compilation of Moggallāna, however, after the words "thero bodhesi räjānam vatvā Tittirajātakam," the whole Jataka, i.e. a versification of the commentary, including the stanzas, is inserted, beginning with-

Atīte Brahmadattamhi kārente bhavanam kira samiddhe nagare ramme pure Bārānasĩvhaye.

This addition consists of thirty slokas, and it is connected with the 'Rahmenerzählung,' so to speak, by the words-

tam dhammadesanam sutvā rājā attamano tato vasanto garu sattāham rājuyyāne manorame sikkhāpetvā mahīpālaṃ sambuddhasamayạ̣ varạ̣.

The verb fin. is missing, as often, and 'garu' instead of 'tattha' (reading of the printed text) was needed, in order to remind the reader that Tissa is spoken of in the second half of the sloka (which, in our case, has an additional line): 
For a fuller report on this singular work, its sources and composition, I may be allowed to refer to my new edition of the Mahāvamsa now in preparation.-Yours faithfully,

E. Hardy.

\section{A Sanskrit Maxim.}

\section{Redlill.}

November 25, 1901.

Dear Professor Ruys Davids,-In the Preface to my pamphlet on Sanskrit Maxims, which was published last year and noticed in this year's July number of the R.A.S. Journal, I gave a short list of nyāyas contained in the lexicons, but which I had failed to find in the literature. Amongst them was the andhagajanyaya, "the maxim of the blind men and the elephant." I have since discovered it, however, in Sureśvara's huge vārtika on Brhadāranyakopanișadbhāṣa, 4. 4. 566 (p. 1813 of Ānandāśrama edition). The verse is as follows:-

“ Ekam evaikarūpam sadvastvajñātam nirañjanam| Jātyandhagajadrsstyeva koțisuh kalpyate mṛșā." ||

But a much more interesting fact in connection with this nyãya is that the story on which it is based is of Buddhistic origin. Several months ago Monsieur Barth informed me that he had met with it in some Buddhist work which he could not then remember; and now the missing link has been supplied by Monsieur Louis de la Vallée Poussin, who referred me to p. 187 of your Dialogues of the Buddha. It is there stated that the story was told by Gotama himself to a number of non-Buddhist teachers who were disputing as to the meaning of the Ten Indeterminates ("Whether the world is eternal or not," etc.), and I now learn from yourself that the original is contained in Udanna, vi, 4, pp. 66-69 of the Pali Text Society's edition.

I hope to embody this information in a Second Handful of Sanskrit Maxims which $I$ have in the press. - Yours sincerely,

G. A. JАCOB. 